\title{
Heterologous Expression of Potato Virus Y Coat Protein, Isolate Pot187
}

\author{
Nemat Sokhandan Bashir 1,*, Mahin Poorsmaile 1, Mohammad Hajizadeh 2 \\ ${ }^{1}$ Department of Plant Protection, Faculty of Agriculture, University of Tabriz, Tabriz, Iran \\ ${ }^{2}$ Department of Plant Protection, Faculty of Agriculture, University of Kurdistan, Sanandaj, Iran \\ ${ }^{*}$ Corresponding author: Nemat Sokhandan Bashir, Department of Plant Protection, University of Tabriz, Tabriz, Iran. Tel: +98-4133392036, Fax: +98- \\ 4133356006, E-mail: sokhandan@tabrizu.ac.ir
}

Received: January 17, 2015; Revised: September 07, 2015; Accepted: September 26, 2015

\begin{abstract}
Background: The advent of recombinant DNA technology has facilitated heterologous expression of proteins from various sources in different host systems including Escherichia coli. If a plant virus coat protein is expressed in the bacterium it can be used as the antigen for antibody preparation. Such a recombinant antigen preparation can be particularly useful where equipment such as ultracentrifuge is unavailable to purify virus particles to use as the antigen for conventional antibody preparation.

Objectives: Heterologous protein expression and purification of the full length Potato virus $Y$ (PVY) coat protein $(\mathrm{CP})$ from isolate pot187 (an affiliate of strain $\mathrm{N}$ ) to be used as an antigen was the aim of the study.

Materials and Methods: Reverse transcription Polymerase Chain Reaction (RT-PCR) was carried out to amplify an 801 bp fragment of the CP gene from PVY-infected potato leaves. The amplicon was cloned into pGEM-T Easy. The cloned fragment was restricted by $\mathrm{BamHI}+\mathrm{SacI}$ and the purified fragment was cloned into the expression vector pET21a(+) which was restricted with the same enzymes. The generated plasmid was introduced into E. coli strain Rosetta ${ }^{\mathrm{TM}}$. The expression was induced with isopropyl- $\beta$-D-thiogalactopyranoside (IPTG) and its protein content was subjected to SDSPAGE and western blotting.

Results: SDS-PAGE analysis of protein from the induced bacteria showed a $\sim 35 \mathrm{KDa}$ protein corresponding to PVY CP. Expression of the recombinant protein was confirmed by anti-His anitibody.

Conclusions: The full-length cDNA of PVY-CP was amplified from the infected potato leaves. The cDNA was heterologously expressed in E. coli. The produced recombinant $\mathrm{CP}$ can be used as an antigen to generate polyclonal antibody.

Keywords: Cloning; Coat protein; E. coli; Expression; PCR; PVY-pot187; Recombinant
\end{abstract}

\section{Background}

Potato virus $Y$ (PVY) is the type species of the genus Potyvirus, family Potyviridae. Potyvirus is accounted for one-third of viral infections in crops (1). PVY has a wide host range in Solanaceae, Amaranthaceae, Fabaceae, Chenopodiaceae, and Asteraceae. PVY causes significant losses in four main crops, potato, pepper, tomato and tobacco around the world. The most frequently occurring symptoms are mosaic, mottling, deformation, spotting and chlorosis on leaves, and necrotic ring spots on the tubers (2). PVY is transmitted in a non persistent manner by more than 50 aphid species among which Myzus persicae is the most efficient vector (3).

PVY strains PVYO, PVYN, PVYC, PVYNTN and PVYN $-\mathrm{W}$ are recognized by their distinct host responses (4-6). PVYO causes mosaic and mottling and the tobacco veinal necrosis strain $\left(\mathrm{PVY}^{\mathrm{N}}\right)$ causes necrotic symptoms in N. tabacum. Stipple streak strain $(\mathrm{PVYC})$ induces hypersensitivity in many potato cultivars, and both PVYNTN (potato tuber necrotic ring disease) and PVYN-W infect potato cultivars.

PVY particles are flexuous rods of $\sim 750 \mathrm{~nm}$ in length and 11-15 $\mathrm{nm}$ in diameter, and consist of capsid proteins arranged in a helical symmetry around the RNA genome. The single-stranded, positive-sense genomic RNA ( 9.7-10 kb) of PVY has a viral genome-linked protein ( $\mathrm{VPg}$ ) at the $5^{\prime}$ of the genome and poly (A) at $3^{\prime}$ ends. The RNA encodes a single, large polypeptide that is cleaved by three viral-encoded proteases into 10 proteins including P1, HC-Pro, P3, 6K1, CI, 6K2, NIa-Vpg, NIa-Pro, NIb and CP proteins (7). Coat protein (CP) protects the RNA genome, involves in aphid transmission, cell-to-cell movement 
and also contributes to the viral genome amplification. The $\mathrm{CP} \mathrm{NH}_{2-}$ and $\mathrm{COOH}$-terminal residues are exposed so that mild trypsin treatment removes the termini leaving a core of $\sim 24 \mathrm{kDa}$.

Expression of foreign genes such as viral $\mathrm{CP}$ in $E$. coli is relatively fast and inexpensive for producing high quantities of proteins (8). Besides, fusion of tags to the expressed proteins produced in $E$. coli facilitates their purification. The CP gene of several plant viruses have been expressed in $E$. coli as recombinant antigens for raising virus-specific antibodies $(9,10)$. As to PVY, expression of the CP gene from Wilga isolate of PVY has been reported (11). In Iran, a report on expression of PVYN CP gene in potato plants has been published recently (12); however, to the best of our knowledge there is no report on expression in bacteria.

\section{Objectives}

This study aimed at expressing of PVY CP gene in $E$. coli from a native isolate known as pot187 (13). The recombinant $\mathrm{CP}$ can be used as an antigen in preparation of viral-specific antibodies for serological detection of the virus.

\section{Materials and Methods}

\subsection{Virus Source and RT-PCR}

PVY-pot187 originally isolated from potato in Ardabil province, Iran (13). PVY-pot187 was used as the source isolate to amplify the CP gene. It was propagated in potato, Solanum tuberosum via mechanical inoculation with the use of $0.1 \mathrm{M}$ potassium phosphate $\mathrm{pH}$ 7.4. Total RNA was isolated from $100 \mathrm{mg}$ leaves of infected potatos four weeks post-inoculation (14).

Sequences of PVY CP isolates were retrieved from GenBank, aligned and a consensus sequence based on frequencies of substituted nucleotides was determined in GeneDoc program (15) and used as the template for primer design. The forward PVY CP-F 5'CACGGATCCGGAAATGACACAATTGATGC3' and reverse PVY CP-R 5'CACGAGCTCTCATGTTCTTAACTCCAAGTAG3' primers were designed corresponding to nucleotides 8566-8585 and 9347-9366 of PVY isolate Iung-2 (GenBank accession JF927750) using Oligo 5 (16). A fragment (819 bp) encoding CP protein with engineered restriction sites BamHI and $\mathrm{SacI}$ sites (underlined) was amplified. The native stop codon was removed from PVY CP-R to allow the reading frame continue through the C-terminal His*Tag of pET-21a (+) (Novagen, USA). This vector provides T7*Tag and His*Tag which are fused to the expressed protein and, therefore, facilitate solubility and purification of the expressed protein. All the reagents were purchased from (Fermentas, Lithuania). Reverse transcription was performed in $10 \mu \mathrm{L}$ reaction containing 2 $\mu \mathrm{L}$ (out of $20 \mu \mathrm{L}$ purified total RNA) of leaf RNA, 0.4 $\mu \mathrm{L}$ of PVY CP-R (5 pmol. $\left.\mu \mathrm{L}^{-1}\right)$ and $1.1 \mu \mathrm{L}$ RNase-free sterile distilled water. The mixture was incubated at $70^{\circ} \mathrm{C}$ for $5 \mathrm{~min}$, immediately placed on ice and $7.5 \mu \mathrm{L}$ of reverse transcription mix containing $2 \mu \mathrm{L}$ of reverse transcriptase buffer, $10 \mathrm{mM}$ dNTPs, 20 Units RNAsin and 80 Units $\mathrm{M}-\mathrm{MuLV}$ reverse transcriptase was added into each reaction to a final volume of $10 \mu \mathrm{L}$. The reaction mixtures were incubated at $25^{\circ} \mathrm{C}$ for $10 \mathrm{~min}, 4^{\circ} \mathrm{C}$ for $60 \mathrm{~min}$ and $70^{\circ} \mathrm{C}$ for $10 \mathrm{~min}$ in a CG1-960 thermo cycler (Corbett Research, Australia). PCR reaction was performed in $25 \mu \mathrm{L}$ reaction containing $2 \mu \mathrm{L}$ of the synthesized cDNA, $1 \times$ PCR buffer, $2 \mathrm{mM} \mathrm{MgCl} 2,2$ pmol each primer, $5 \mathrm{mM}$ dNTPs and 1 Unit Taq DNA polymerase. The PCR was started at $94^{\circ} \mathrm{C}$ for $2 \mathrm{~min}$, followed by 35 cycles of $94^{\circ} \mathrm{C}$ for $45 \mathrm{~s}, 50^{\circ} \mathrm{C}$ for $45 \mathrm{~s}$ and $72^{\circ} \mathrm{C}$ for $45 \mathrm{~s}$. A final extension at $72^{\circ} \mathrm{C}$ for $10 \mathrm{~min}$ was also applied. The products were run on $1.2 \%(\mathrm{w} / \mathrm{v})$ agarose in $0.5 \times$ TBE buffer, stained with ethidium bromide and photographed by Gel- Digi doc (Kiagen, Tehran, Iran).

\subsection{Cloning}

The PCR product was first ligated into the cloning vector pGEM-T Easy (Promega, USA). The amplicon (20 ng) was added into a $10 \mu \mathrm{L}$ (final volume) ligation mix containing $1 \times$ ligation buffer, 50 ng pGEM-T Easy and 1 unit $T_{4}$ DNA ligase. The reaction was kept at $22^{\circ} \mathrm{C}$ for $90 \mathrm{~min}$ before placing at $4{ }^{\circ} \mathrm{C}$ for $16 \mathrm{~h}$. The ligation mix $(1 \mu \mathrm{L})$ was used to transform $E$. coli DH5 $\alpha$ competent cells (13). Both the recombinant pGEM-T Easy and pET21a (+) vectors were digested with Bam HI + SacI. The released CP fragment and linearized pET21a $(+)$ were purified from agarose gel by the use of QIAquick Spin kit (Qiagen, Australia). The purified fragments were ligated before introducing to $E$. coli strain Rosseta. The resultant recombinant pET21aPVYCP was sequenced with the T7- promoter and Terminator primers in Bioneer (Germany) and submitted to BLAST analysis (17) to ascertain identity of the amplified fragment as PVY CP.

\subsection{Expression of the PVY-CP Gene in E. coli}

Overnight culture of $E$. coli $(200 \mu \mathrm{L})$ carrying pET21aPVYCP or pET-21a (+) (control) was inoculated into $10 \mathrm{~mL}$ fresh LB containing $0.1 \mathrm{mg} \cdot \mathrm{mL}^{-1}$ ampicillin and grown to an optical density of 0.6 before 
induction with $0.1 \mathrm{mM}$ final concentration of IPTG (isopropyl- $\beta$-D-thiogalactopyranoside). The culture was further grown for $3 \mathrm{~h}$ at $37^{\circ} \mathrm{C}$ and $1.5 \mu \mathrm{L}$ of the bacteria was pelleted by centrifugation at $15000 \mathrm{~g}$ for $1 \mathrm{~min}$. The pelleted cells were resuspended in $100 \mu \mathrm{L}$ of Laemmli buffer (18) and stored at $-24^{\circ} \mathrm{C}$ for further analysis.

\subsection{SDS-PAGE and Western Blotting}

The pelleted bacteria were boiled for $2 \mathrm{~min}$ and 15 $\mu \mathrm{L}$ aliquots were run on $12 \%$ polyacrylamide gel containing SDS and stained with Coomassie Brillant Blue. The separated proteins (unstained) were electro-blotted onto a nitrocellulose membrane in a wet system (Akhtarian, Tabriz, Iran). After blocking with 2\% BSA, the membrane was incubated for $2 \mathrm{~h}$ with mouse anti- His*Tag antibody $(1: 1000)$. The secondary antibody and universal alkaline phosphatase-conjugated rabbit anti mouse (1:1000), were added and incubated at $22^{\circ} \mathrm{C}$ for $2 \mathrm{~h}$. After each step, the membranes were washed three times with PBS-Tween 20 (PBS-T). The membrane was incubated in the freshly prepared substrate, nitro blue tetrazolium (NBT,100 $\mu \mathrm{L})$ and 5bromo-4-chloro-3-indolyl phosphate (BCIP, $50 \mu \mathrm{L}$ ) in $100 \mathrm{mM}$ Tris buffer, $\mathrm{pH} 9.5$ containing $100 \mathrm{mM} \mathrm{NaCl}$ and $0.1 \mathrm{MgCl}_{2}$.

\section{Results}

\subsection{Isolation, Amplification and Cloning}

Leaves of S. tuberosum inoculated with PVY-pot 187 showed mosaic, rugose and yellowing 10-15 days post inoculation. RT-PCR on total RNA isolated from the infected leaves resulted in a DNA fragment of a $~ 801$ bp corresponding to PVY CP (Figure 1A). BLAST analysis of the obtained nucleotide sequence for PVYCP revealed 97\% similarity with PVY strain NTN (GenBank accession AY840082). The PVY-pot187 CP sequence was submitted to GenBank under the accession number KJ865800.

When the $C P$ cDNA and linearized pET21(+) were purified from gel (Figure 1A), ligated and transformed into E. coli strain Rosetta, subsequent BamHI + SacI digestion of the extracted plasmids confirmed presence of CP gene (Figure 1B). Sequencing of the recombinant $\mathrm{pET} 21 \mathrm{aPVYCP}$ reconfirmed correct insertion of the $\mathrm{CP}$ fragment into the vector.

\subsection{Expression of the PVY-CP Gene in E. coli}

SDS-PAGE revealed heterologous expression of an about $35 \mathrm{kDa}$ protein corresponding to PVY CP. The
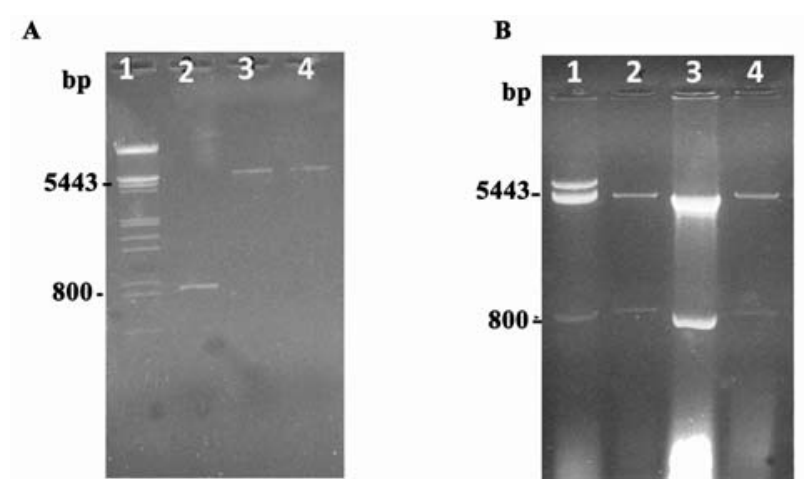

Figure 1. Analyses on 1.2\% agarose of gel-purified Potato virus $\mathrm{Y}$ coat protein cDNA and linearized pET21a $(+)(\mathrm{A})$ and restriction analysis of the cloned fragment (B). (A) lane 1: lambda DNA EcoRI + HindIII, lane 2: purified PVY CP cDNA, lanes 3-4: linearized vector (replicate samples). (B) restriction analysis of recombinant pET21a $(+)$ carrying the insert after cloning in Escherichia coli DH5a. Lane 1: A previously identified pET-21aPVYCP used as a size marker, lanes 2-4: recombinant plasmids from three colonies transformed with pET-21aPVYCP

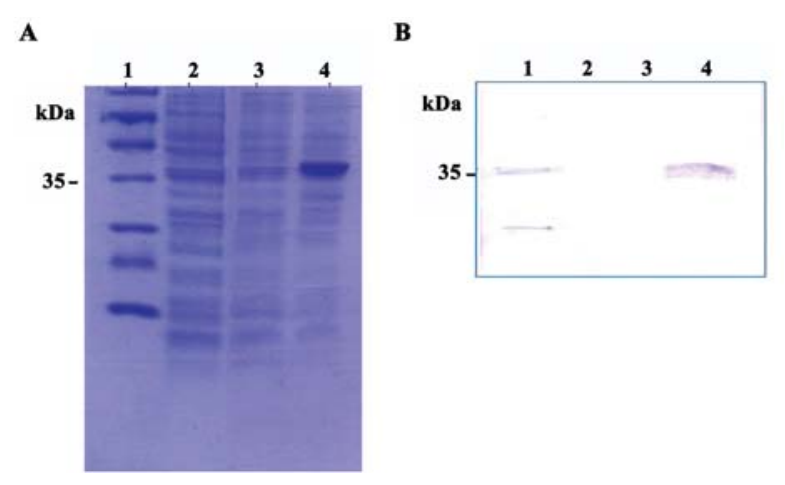

Figure 2. A: SDS-PAGE and B: western blot analyses of Potato virus Y coat protein expressed in Escherichia coli. (A), lane 1: protein size marker (Fermentas, Lithuania), lane 2: sample from bacteria containing pET21a $(+)$ with no CP insert, lane 3: E. coli containing pET21aPVYCP noninduced, lane 4: the same as lane 3 but induced with $1 \mathrm{mM}$ $\mathrm{M}$ IPTG and grown for $4 \mathrm{~h}$ afterwards. (B) The lanes correspond to that of (A) after subjecting to western blotting with anti-His•Tag

maximum expression was obtained $3 \mathrm{~h}$ post induction (Figure 2A). Western blot indicated presence of a 35 $\mathrm{kDa}$ recombinant protein using anti-His*Tag antibody (Figure 2B).

\section{Discussion}

Because the main control measure against plant viruses is rather prevention, timely application of detection techniques is crucial. PVY CP specific 
primers were designed and full-length PVY CP gene (801 bp) was efficiently amplified in this study for the gene expression purpose whereas others have used degenerate primers (19) because degenerate primers are sufficient for detection purposes only and not for the expression purpose as pursued in this study (16).

Sequence of the amplified fragment revealed a close relatedness of PVY-pot187 to PVY isolate Iung2 (PVYNTN strain group) (5) which also agreed with the report (31) which suggests the studied Iranian PVY isolates might be relatives of PVYNTN. This is a derivative of $\mathrm{PVY}^{\mathrm{N}}$ strain, which induces vein necrosis in tobacco leaves and provokes PTNRD and severe chlorotic mosaic in potato leaves (5).

A few studies have dealt with PVY from Iran (20), but to the best of our knowledge there is no report concerning expression of the virus $\mathrm{CP}$ gene in E. coli. Analysis showed that the $\mathrm{CP}$ can be efficiently expressed via pET21a $(+)$ in E. coli (Figure 2A). Induction with $0.1 \mathrm{M}$ IPTG before growing for $3 \mathrm{~h}$ resulted in a $\sim 35 \mathrm{KDa}$ (including the Tag sequences) intense protein band corresponding to PVY CP, which was absent in non-induced bacteria or in bacteria that had no $C P$ gene. Fusion of His $\bullet$ Tag allowed us to use anti-His $\bullet$ Tag antibody to confirm the expression of a recombinant protein in western blot.

\section{Conclusions}

This study demonstrated usefulness of biotechniques in precise isolation of PVY CP gene from isolate PVY-pot187. The expressed CP can be used as the antigen for antiserum preparation. It may also facilitate further research on PVY and establishment of resistance against the virus.

\section{Acknowledgements}

We thank Iran National Science Foundation (INSF) for financial support of this project.

\section{Authors' contribution}

Nemat Sokhandan Bashir acted as the chief investigator and prepared the manuscript, Mahin Poorsmaile performed the lab work and Mohammad Hajizadeh was the associate supervisor.

\section{References}

1. Ordoudi SA, Tsermentseli SK, Nenadis N, Assimopoulou AN, Tsimidou MZ, Papageorgiou VP. Structure-radical scavenging activity relationship of alkannin/shikonin derivatives. Food Chem. 2011;124(1):171-176. DOI: 10.1016/j.foodchem.2010. 06.004

2. Petrov N, Andonova R. Bion and exin as sar elicitors against
Potato virus Y infection in tomato. Sci Technol. 2012;2(6):4649.

3. Kanavaki OM, Margaritopoulos JT. Transmission of potato virus $\mathrm{Y}$ in tobacco plants by Myzus persicae nicotianae and $M$. persicae s. str. Plant Dis. 2006;90:777-782. DOI: http://dx. doi.org/10.1094/PD-90-0777

4. Tribodet M, Glais L, Kerlan C, Jacquot E. Characterization of potato virus $\mathrm{Y}$ (PVY) molecular determinants involved in the vein necrosis symptom induced by PVYN isolates in infected Nicotiana tabacum cv. Xanthi. J Gen Virol. 2005;86:21012105. DOI: 10.1099/vir.0.80926-0

5. Inoue-Nagata AK, Fonseca MEN, Lobo TOTA, Deavila AC, Monte DC. Analysis of the nucleotide sequence of the coat protein and 3'-untranslated region of two Brazilian potato virus Y isolates. Fitopatol Brasil. 2001;26:45-52. DOI: http://dx.doi.org/10.1590/S0100-41582001000100008

6. Chrzanowska M. New isolates of the necrotic strain of Potato virus Y $\left(\mathrm{PVY}^{\mathrm{N}}\right)$ found recently in Poland. Potato Res. 1991;34:179-182. DOI: 10.1007/bf02358039

7. King AMQ, Adams MJ, Carstens EB, Lefkowitz EJ. Virus taxonomy, classification and nomenclature of viruses. Ninth report of the International Committee on Taxonomy of Viruses. UK: Academic Press; 2012.

8. Hartley JL. Cloning technologies for protein expression and purification. Curr Opin Biotechnol. 2006;17:359-366. DOI: 10.1016/j.copbio.2006.06.011

9. Lee SC, Chang YC. Performances and application of antisera produced by recombinant capsid proteins of Cymbidium mosaic virus and Odontoglossum ringspot virus. Eur J Plant Pathol. 2008;122:297-306. DOI: 10.1007/s10658-008-9293-2

10. Abou-Jawdah Y, Sobh H, Cordahi N, Kawtharani H, Nemer G, Maxwell DP, Nakhla MK. Immunodiagnosis of Prune dwarf virus using antiserum produced to its recombinant coat protein. J Virol Methods. 2004;121:31-38. DOI: 10.1016/j. jviromet.2004.05.013

11. Folwarczna J, Plchová H, Moravec T, Hoffmeisterová H, Dědičb P, Čeřovská N. Production of polyclonal antibodies to a recombinant coat protein of Potato virus Y. Folia Microbiol. 2008; 53:438-442. DOI: 10.1007/s12223-008-0067-1

12. Ansari Dezfoli E, Massumi H, Hashemi H. Transformation and experssion of the coat protein genes of Potato virus $\mathrm{Y}$ and Potato virus S Iranian isolates in Solanum tubersum var Agria lines. Agric Biotech. 2013;4:35-45.

13. Sokhandan-Bashir N, Ghasemzadeh A, Masoudi N, Khakvar R, Farajzadeh D. Degenerate primers facilitate the detection and identification of potyviruses from the northwest region of Iran. Iran J Biotech. 2013;11:115-122.

14. Bashir NS, Hajizadeh M. Survey for grapevine fanleaf virus in vineyards of north-west Iran and genetic diversity of isolates. Austral Plant Pathol. 2007;36(1):46-52. DOI: 10.1071/ AP06080

15. Nicholas KB, Nicholas Jr HB. Gene Doc: a tool for editing and annotating multiple sequence alignments. Distributed by the author; 1997.

16. Wojciech R. Oligo Primer Analysis Software version 5.0. Published by National Biosciences Inc., MN, USA. 1994.

17. Altschul SF, Gish W, Miller W, Myers EW, Lipman DJ. Basic local alignment search tool. J Mol Biol. 1990;215:403-410. 
DOI: $10.1016 / \mathrm{S} 0022-2836(05) 80360-2$

18. Laemmli UK. Cleavage of structural proteins during the assembly of the head of bacteriophage T4. Nature (London). 1970;227:680-685. DOI: 10.1038/227680a0

19. Amer MA, El-Hammady MH, Mazyad HM, Shalaby AA, AboElabbas FM. Cloning, expression and nucleotide sequence of coat protein gene of an Egyptian isolate of potato Virus Y Strain NTN infecting potato plants. Egypt J Virol. 2004;1:39-50. DOI: 10.3923/ijv.2005.3.3

20. Hosseini A, Massumi H, Heydarnejad J, Hosseini Pour A. Varsani A. Characterisation of potato virus Y isolates from Iran. Virus Genes. 2011;42:128-140. DOI: 10.1007/s11262-010-0546-8 